\title{
First Record of Polyphagotarsonemus latus in Saudi Arabia
}

\author{
Mahmoud M. Al-Azzazy ${ }^{1,2} \&$ Saleh S. Alhewairini ${ }^{1}$ \\ ${ }^{1}$ Department of Plant Production and Protection, College of Agriculture and Veterinary Medicine, Qassim \\ University, Saudi Arabia \\ ${ }^{2}$ Agricultural Zoology and Nematology Department, Faculty of Agriculture, Al-Azhar University, Cairo, Egypt \\ Correspondence: Saleh S. Alhewairini, Department of Plant Production and Protection, College of Agriculture \\ and Veterinary Medicine, Qassim University, P.O. Box 6622, Buraidah 51452, Al-Qassim, Saudi Arabia. Tel: \\ 966-163-801-360. E-mail: hoierieny@qu.edu.sa
}

Received: August 2, 2018

doi:10.5539/jas.v10n12p228
Accepted: September 9, $2018 \quad$ Online Published: November 15, 2018

URL: https://doi.org/10.5539/jas.v10n12p228

\begin{abstract}
Several species of vegetables and fruits are attacked by many Tarsonemid mites. This includes the broad mite, Polyphagotarsonemus latus Banks (Acari: Tarsonemidae). P. latus is widely distributed world-wide and has more than 60 host plants. In this study, it has been reported on peppers, Capsicum annuum L. (Solanaceae), for the first time in Saudi Arabia. This is the second record of P. latus from the Arabian Peninsula, after Oman. The mite population was recorded 6 times at 15 day intervals from September to the end of November on six leaves per plant, two each from the top level, middle level and bottom level selected at random. Therefore, more successvie research studies are needed for maganement and control of this pest.
\end{abstract}

Keywords: broad mite, tarsonemidae, Saudi Arabia, Polyphagotarsonemus latus, greenhouse peppers

\section{Introduction}

Tarsonemid mites have recently become very important acarine pests infesting several species of vegetables and fruit trees. The tarsonemid broad mite, Polyphagotarsonemus latus (Banks), is considered as the most injurious tarsonemid mites. It is distributed world-wide and infests more than 60 host plants, according to Gerson (1992) $P$. latus was recorded in Asia in 1979, where the symptoms on leaves are known as "Aquarius" (Kabir AKMF, 1979). During 1979, there were scattered mite infestations in a few greenhouses, but in the following seasons it became an increasingly economically important pest of peppers. In Egypt for example, it was recorded on pepper plants by Abou Awad as well as other vegetables whether in open fields or in greenhouses (Mostafa, 2007). It has also been found on some plants of the family Cucurbitaceae (Grinberg et al., 2005). In Asia, it was first reported in Indonesia on Java (Kalshoven, 1950), followed by Bangladesh (Kabir, 1979), Taiwan (Wen and Lee, 1984), Oman (CIE, 1986), Sri Lanka (CIE, 1986), Israel (Palevsky et al., 2001), Thailand (Waterhouse, 1993), the Islamic Republic of Iran (Masoud et al., 2001), Turkey (Bulut et al., 2000), South Korea (Cho et al., 1996), Vietnam (Duong-Nguyen Hai et al., 1998), Iraq (Al-Ani et al., 2008) and the Philippines (Navasero et al., 2014) (Figure 3). In addition, P. latus cannot be easily seen as it is tiny and broad mite damage is often. Thus, this results in a mistake for a virus infection on pepper cultivars as its infection is easily detected. This includes the difficulty in distinguishing the larval or adult female mites. It is also reported to act as a vector of leaf curl virus (Chakraborti, 2000). Ewing (1939) published the first comprehensive taxonomic work on mites belonging to the family Tarsonemidae. They are small mites with broad elongated oval bodies; the integument is hard and shiny. They have only two active stages, larvae and adults. Some feed on green plants (a few are important agricultural pests), while others prefer fungi and several are associated with arthropods.

According to the review of Ewing (1939), Beer (1954), and Lindquist (1986), the position classification of the broad mite $P$. latus has undergone many changes. In Sri Lanka, it was initially collected and described in 1890 from tea as Acarus translucens Green. Thereafter, it has an independent name as Tarsonemus latus (Banks) in 1904, based on samples collected from mango seedlings in the United State of America. The latter name became accepted upon the realization that A. translucens was already in USA. Ewing (1939) thereafter placed latus under genus Hemitarsonemus, from which it was later transferred by Beer and Nucifora (1965) to their new genus Polyphagotarsonemus. Lindquist (1986) more recently redefined and fully reclassified both Polyphagotarsonemus and latus. 


\section{Materials and Methods}

In the present work, mite individuals of the broad mite, P. latus (Banks, 1904) (Tarsonemidae), were collected in September 2017 from unsprayed greenhouse sweet pepper plants, Capsicum annuиm L. (Solanaceae), in the Qassim region, Saudi Arabia. Pepper leaves and fruit were randomly collected and placed in a clean labeled plastic bag and transported to the Department of Plant Production and Protection laboratory, College of Agriculture and Veterinary Medicine, Qassim University for immediate examination of the mites under a stereomicroscope. Mite individuals were mounted in Modified Dioni's (2003) medium and the microscopic slides were dried in a hot oven $\left(40-50^{\circ} \mathrm{C}\right)$ for two weeks, then dried slides were sealed around the cover slip.

The mite population was recorded 6 times at 15 day intervals from September to the end of November on six leaves per plant, two each from the top level, middle level and bottom level selected at random. The mite population counts were recorded under a binocular microscope from leaves by direct observation.

\section{Results and Discussion}

In current research, mites infesting peppers were identified according to Lindquist (1986). The adult females are dark green with an indistinct white strip in the mid-dorsum. The adult males are broadly short and tapered posteriorly. They become rich amber when fully developed, although they are colourless at first stage. Males have relatively longer legs than females and are only half as long as females. They also lack the white dorsal stripe present in the mid-dorsum of females. The prodorsal shield is not enlarged to cover the stigmata. The prodorsum has a pair of captitate trichobothria and two pairs of setae. The dorsal idiosomal setae are short. The metapodosomal venter has 4 pairs of setae. Tibiotarsus I has a single strong claw. There are four pairs of setae on the prodorsum in the male. Leg IV of the adult male has a button-like claw, which is characteristic of this species (Jeppson et al., 1975; Lindquist, 1986; Lin \& Zhang, 2002). The infestation of P. latus can cause damage in the growth of the terminal shoots and young leaves. Various symptoms of its infestation can be seen on leaves as they rolling toward the lower surface, the blade becoming corrugated in appearance, and buds are aborted, flowers distorted and fruit may be malformed. This restlued in stopoing the development of the plant as it then appears dwarfed (Figure 1). Furthermore, the eggs of P. latus are commonly present and the adult mites may be absent, although damage symptoms may be obvious. This pest mite sucks plant juice and injects toxic salivary secretions into the plant sap (Gerson, 1992). Individuals of P. latus are found on the rear surface, but may also be found on the upper leaf surface when the population is high. They concentrate beside the central and secondary veins, occasionally occupying the whole leaf surface (Smith, 1939; Schoonhoven et al., 1978); more often the mite prefers feeding on the lower leaf surfaces, which consequently curl downwards.
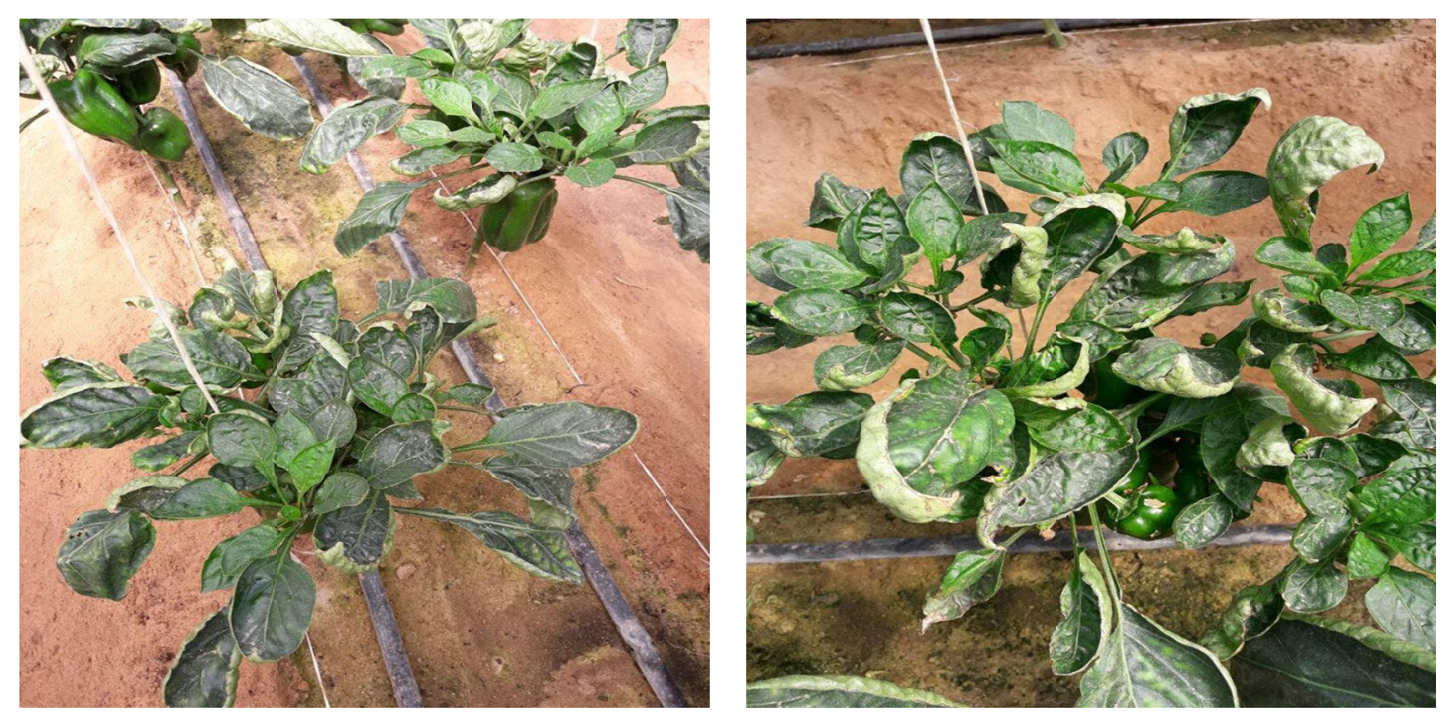

Figure 1. Infestation symptoms of $P$. latus (Banks, 1904) on pepper leaves photos 


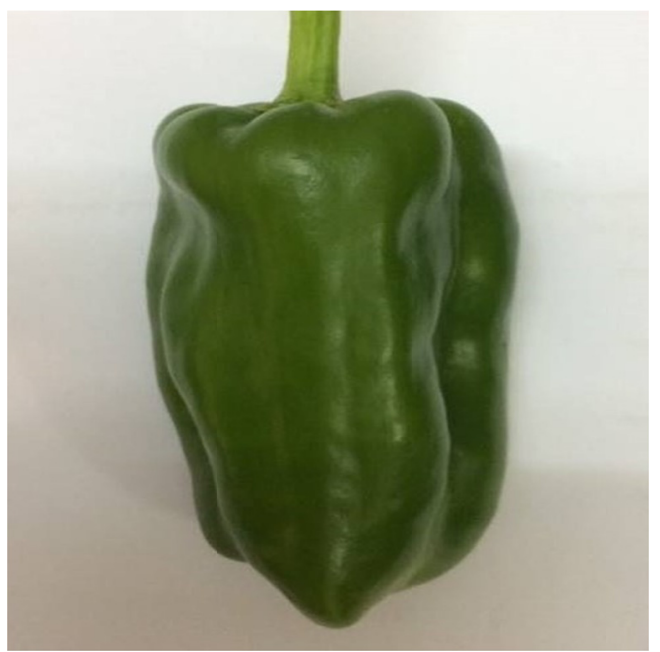

(A)

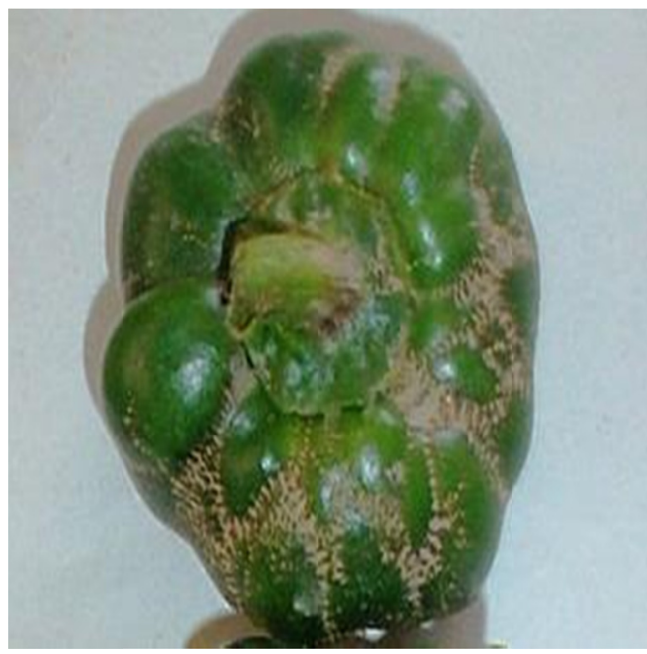

(B)

Figure 2. (A) Healthy sweet pepper fruit and (B) infested by P. latus (Banks, 1904)

\section{Field Observations Recorded During the Growing Season}

Vertical distribution of the phytophagous mite P. latus occurs from early September to late November 2017. It was found that its density gradually increased from the second week of September, reached its peak in mid of October and started declining from late November. At the bottom level, the leaves had significantly lower numbers of species in comparison to the top and middle leaves. The behavioural bindings are in general agreement with those obtained by Palevsky et al. (2001), Farahat (2011), and Abd El-Nasser et al. (2016). The determination of unknown factors is very important in this research and can open more successive research such as how to control this pest. Therefore, further investigations might be required for seasonal incidence which can help in formulating (IPM) Integrated Pest Management schedule.

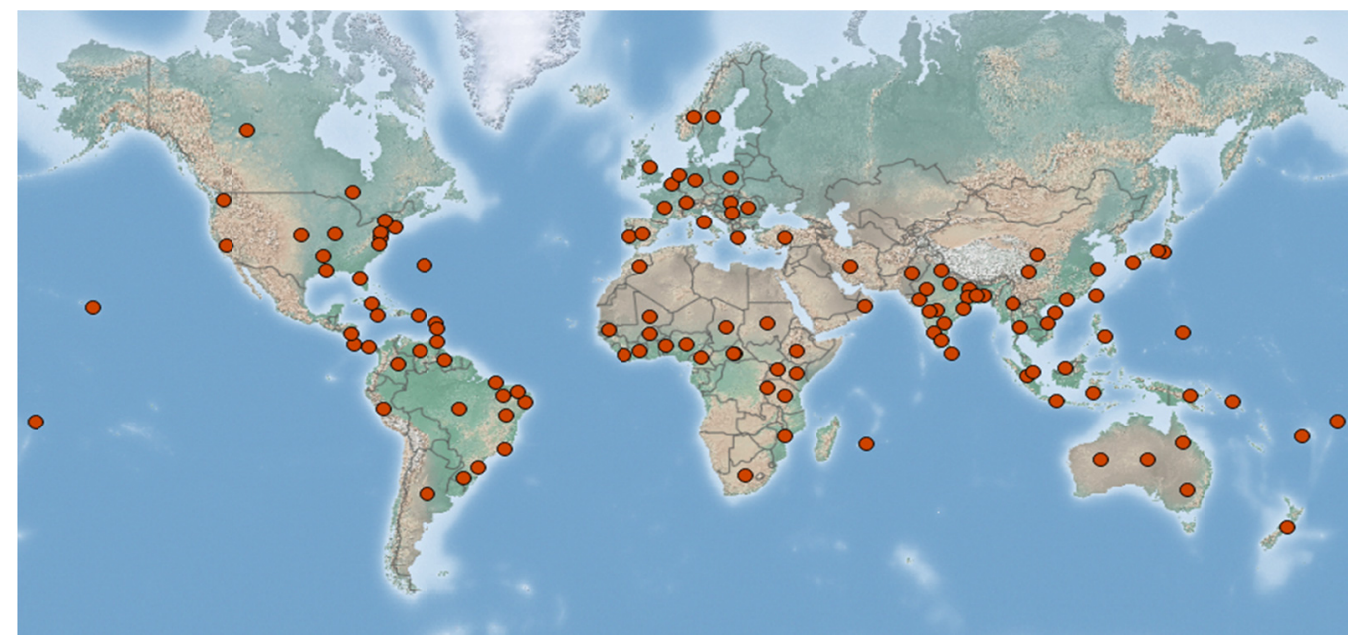

Figure 3. Distribution map of the phytophagous mite P. latus (reprinted by the C.A.B. International Institute of Entomology)

\section{Acknowledgments}

The authors gratefully acknowledge Dr. Mohamed Motawei and Dr. Mohammad Al-Deghairi for revising this manuscript. 


\section{References}

Abd El-Nasser, T., \& Hassan. (2016). Population Dynamics of Polyphagotarsonemus latus (Banks) (Acari: Tarsonemidae) on Common Potato Cultivars in Egypt. J Biolog Sci, 4, 173-180.

Al-Ani, L. K., \& Al-Jbooryv, I. I. (2008). Effect of Different Temperatures on the Biology of the Broad Mite Polyphagotarsonemus latus (Banks) on Potato. Arab J Pl Prot, 26, 95-101.

Banks, N. (1904). Class III, Arachnida, Order 1, Acarina, four new species of injurious mites. J. N. Y. Entomol. Soc., 12, 53-56.

Beer, R. E., \& Nucifora, A. (1965). Bollettino di Zoologia Agraria e di Bachicoltora. Serie II, 7, 19-43.

Bulut, E., Gocmen, H., Albajes, R., \& Sekeroglu, E. (2000). Pests and their natural enemies on greenhouse vegetables in Antalya. Bulletin OILB SROP, 23, 33-37.

Chakraborti, S. (2000). Neem-based integrated schedule for the control of victors causing apical leaf curling in chilli. Pest Manag Eco Zool., 8, 79-84.

Cho, M. R., Jeon, H. Y., La, S. Y., Kim, D. S., \& Yiem, M. S. (1996). Damage of broad mite, Polyphagotarsonemus latus (Banks), on pepper growth and yield and its chemical control. Korean J Appl Entomol, 35, 326-331.

CIE. (1986). Distribution Maps of Plant Pests, No. 191. Wallingford, UK: CAB International.

Dioni, W. (2003). Safe Microscopic techniques for amateurs. Mounting Microscopic Subjects, Part 3c-Gum Based Media. Micscape 91-May.

Duong, N., Thanh, H., Doan, T., Yen, N., Tam, T. T. M., Dung, P. T., \& Phuong, L. T. T. (1998). Diseases and pests of Hevea brasiliensis in Vietnam. Symposium on natural rubber (Hevea brasiliensis): Vol. 2, Physiology \& Exploitation and Crop Protection \& Planting Methods Sessions, Ho Chi Minh City, China.

Ewing, H. E. (1939). A revision of the mites of the subfamily Tarsoneminae of North America, the West Indies, and the Hawaiian Islands, U.S. Dept. Agr. Tech. Bull, 653-663.

Farhat, B. M. (2011). Susceptibility of some pepper varieties to Polyphagotarsonemus lotus (Banks) infestation (Acari: Tarsonemidae) (M.Sc. Thesis, Fac. Agric., Ain Shams University).

Gerson, U. (1992). Biology and control of the broad mite, Polyphagotarsonemus latus (Banks) (Acari: Tarsonemidae). Experm Appl Acarol, 13, 163-178. https://doi.org/10.1007/BF01194934

Grinberg, M., Perl-Treves, R., Palevsky, E., Shomer, I., \& Soroker, V. (2005). Interaction between cucumber plants and the broad mite, Polyphagotarsonemus latus: From damage to defense gene expression. Entomolo Exp et Applicata, 115, 135-144. https://doi.org/10.1111/j.1570-7458.2005.00275.x

Kabir, A. (1979). Bioecology and behavior of yellow jute mite. In J. G. Rodriguez (Ed.), Recent Advances in Acarology (pp. 519-523). Academic Press, New York. https://doi.org/10.1016/B978-0-12-592201-2.50073-7

Kalshoven, L. G. E. (1950). The Pests of Cultivated Plants in Indonesia (Part 1). The Hague, Netherlands: W. van Hoeve.

Lin, J. Z., \& Zhang, Z. Q. (2002). Tarsonemidae of the World (Acari: Prostigmata): Key to Genera, Geographical Distribution, Systematic Catalogue and Annotated Bibliography. Systematic \& Applied Acarology Society c/o Department of Entomology, The Natural History Museum, London, UK.

Lindquist, E. E. (1986). The world genera of Tarsonemidae (Acari: Heterostigmata): A morphological, phylogenetic and systematic revision, with a reclassification of family-group taxa in the Heterostigmata. Mem Entomol Soc Canada, 136, 1-517. https://doi.org/10.4039/entm118136fv

Masoud, A., Payman, N., Samed, K., \& Majied, F. (2001). First damage record of Polyphagotarsonemus latus (Banks., 1904) (Acarina: Tarsonemidae) on potato cultivated in Jhiroft of Iran. Appl Entomol and Phytopath, $69(1), 41-42$.

Mostafa, E. M. K. (2007). Ecological and biological studies on the tarsonemid mite Polyphagotarsonemus latus (Banks) (p. 132, M.Sc. Thesis Agric. Zoology and Nematology Dep Fac Agric Cairo Univ).

Navasero, M. M., \& Corpuz-Raros, L. A. (2014). Survey of host plants and predatory mites associated with the broad mite, Polyphagotarsonemus lotus (Banks) (Acari: Tarsonemidae), and other acari in selected provinces in Luzon and Palawan Islands Philippines. Phili Entomol, 28, 1-31. 
Palevsky, E. L., Soroker, V. L., Weintraub, P., Mansour, F., Abo-Moch, F., \& Gerson, U. (2001). How species-specific is the phoretic relationship between the broad mite, Polyphagotarsonemus latus (Acari: Tarsonemidae), and its insect hosts. Exp and Appl Acarol, 25, 217-224. https://doi.org/10.1023/A:1010 645315630

Schoonhoven, A. V., Peidrahita, T., Valderrama, R., \& Galvez, G. (1978). Biologia, danoy control del acaro tropical Polyphagotarsonemus latus (Banks) (Acarina: Tarsonemidae) en frijol. Turrialla, 28, 77-80.

Smith, F. F. (1939). Control of cyclamen and broad mite in gerbera (p. 14). USDA Cir. https://doi.org/10.596 2/bhl.title.64321

Waterhouse, D. F. (1993). The Major Arthropod Pests and Weeds of Agriculture in Southeast Asia. ACIAR Monograph No. 21 (p. 141). Canberra, Australia: Australian Centre for International Agricultural Research.

Wen, H. C., \& Lee, H. S. (1984). The main insect pests on passion fruit in Taiwan. J Agri Res of China, 33, 81-87.

\section{Copyrights}

Copyright for this article is retained by the author(s), with first publication rights granted to the journal.

This is an open-access article distributed under the terms and conditions of the Creative Commons Attribution license (http://creativecommons.org/licenses/by/4.0/). 